Вурста Н.И.

\title{
Исследовательская деятельность учащихся в контексте проблемы развития креативности*
}

Одним из конфликтов в современной образовательной ситуации является противоречие между творческим развитием, креативностью и «технологичностью». Термин «технология» давно перешагнул рамки производства и завоевал новые пространства человеческой деятельности, в том числе сферу образования. Например, в педагогической литературе встречается представление о «технологии личностно-ориентированного образования» [9]. Под технологией обучения мы будем понимать комплекс, состоящий из: «образа» (представления) планируемых результатов обучения; средств диагностики текущего состояния обучаемых; набора моделей обучения; критериев выбора оптимальной модели для данных конкретных условий [4]. В определенных случаях технология выступает как элемент метода, но в контексте рассматриваемой проблемы нам представляется важным понимание технологии как «развертывания» метода, а последнего как «свернутой технологии», которая «отражается в создании учащихся как след, образ метода» [1].

«Технологизация» образовательного процесса не изменила образовательного идеала, которым является развитие творческого потенциала человека [7]. Насколько адекватны цель образования и средства (технологии)? Могут ли прагматичные, структурированные школьные образовательные технологии (по существу модели с заданным результатом) способствовать развитию творческого начала?

Обзор современной психолого-педагагогической литературы показывает, что существует научный и практический интерес к комплексному исследованию проблемы взаимосоответствия технологий обучения и развития творческого потенциала. Анализ этой проблемы лежит, в частности, в области изучения творчества как феномена человеческой деятельности.

Общим местом стало утверждение, что понимание сущности, природы творчества, его психологических механизмов является одной из трудно решаемых задач для психологии личности и ее развития. Одну из оригинальных трактовок креативности предложил А. Маслоу, который разграничил «креативность таланта» и «креативность самоактуализации». По мнению А. Маслоу, креативность самоактуализации «распространена гораздо более широко и имеет более тесную связь с личностью, проявляясь в повседневной жизни не только в великих и очевидных продуктах творчества, но также многочисленными другими способностями, например, в своеобразном чувстве юмора, склонности что-либо делать творчески, например преподавать...» [6, с. 223] Иначе говоря, креативность понимается не с позиции результата (творческого продукта) и не как тот или иной набор личностных черт (например, интеллектуальных способностей: порождать оригинальные идеи;

* Материалы предоставлены научным руководителем - зав.кафедрой педагогики и педагогической психологии, доктором педагогических наук наук, профессором В.Т. Фоменко 
отказываться от стереотипных способов мышления; выдвигать гипотезы), а как реализация человеком собственной индивидуальности. Уникальность человеческой индивидуальности можно рассматривать как некий творческий акт, отсюда понимание креативности как процесса выявления собственной индивидуальности.

Анализ работ отечественных психологов (В.Г. Ананьева, Д.Б. Богоявленской, Н.С. Лейтеса, Я.И. Пономарева и других), посвященных проблеме развития творческих способностей и склонностей, творческого мышления, позволяет выделить ряд положений, которые используются в педагогике при разработке различных аспектов творчества учащихся:

- каждый учащийся обладает способностями к творчеству; творчество учащихся и творчество взрослых имеют одну психолого-педагогическую основу;

- различия проявлений способностей обнаруживаются в деятельности, поэтому эффективность, темпы, динамика изменений, особенности связи с другими личностными компонентами предполагают необходимость индивидуализации процесса обучения;

- творческие способности поддаются развитию; при этом важная роль принадлежит так называемому механизму переноса, обеспечивающему преемственность в развитии этих способностей в различных видах деятельности;

- творческие черты и качества развиваются в процессе овладения содержанием образования и необходим поиск эффективных технологий, как механизма самореализации содержания.

Существенным является вопрос об управлении творческим процессом. С одной стороны, существует тенденция связывать возможности управления с алгоритмизацией творческой деятельности, разработкой приемов, использование которых вело бы к открытию нового. Другая тенденция характеризуется отрицанием прямого управления творческой деятельностью. Речь идет о создании условий, благоприятных для творчества.

Наиболее перспективными образовательными технологиями, в частности, считаются те, что построены на исследовательском поиске школьника в процессе обучения (исследовательское обучение, исследовательский метод). Исследовательские методы давно и активно используются в зарубежной, преимущественно англоязычной психолого-педагогической литературе (Кларин В.М.). В отечественной науке эта тема разрабатывается Леонтовичем А.В., Поддъяковым А.Н., Савенковым А.И. и др.

Исследовательская деятельность (в том числе и школьника) представляет собой особый вид интеллектуально-творческой деятельности, порождаемый в результате функционирования механизмов поисковой активности и строящийся на базе исследовательского поведения. Но если исследование - всегда творчество, в итоге которого добывается новое знание, можно утверждать, что исследовательская деятельность учащихся является важнейшим условием развития творческого потенциала школьника. Иначе говоря, образовательное пространство на основе исследовательского метода представляет собой необходимую питательную среду 
пробуждения и развития креативности. Посредством исследовательской деятельности мы преодолеваем конфликт между технологичностью и креативностью. Перед школой стоит серьезная практическая задача создания модели организации исследовательской деятельности в целостном учебно-воспитательном процессе. В этой модели необходимо найти компромисс между теми требованиями, которые заданы государством в области образования и необходимой для творчества свободой и нерегламентированностью. Таким образом, речь должна идти о разработке и экспериментальной реализации в образовательном процессе школы такой модели организации исследовательской деятельности, которая бы способствовала процессу выявления собственной индивидуальности учащегося.

Одной из ключевыхпроблем при реализации такой модели является поиск надежных методик научного анализа качеств творческой личности. В частности, речь идет о невозможности создания валидного теста креативности из-за противоречия между:

- сущностью теста как стандартизованной процедуры обследования по заданному набору параметров;

- сущностью творчества как выхода за рамки заданного и известного (что отмечал в свое время автор одного из наиболее часто используемых тестов креативности - Э. Торранс).

Безусловно, при исследовании результативности модели организации исследовательской деятельности в контексте развития творческих способностей необходимо использовать имеющиеся методики (тесты Гилфорда, методику креативного поля Д. Б. Богоявленской и другие). Но, на наш взгляд, исследовательское обучение создает дополнительные возможности анализа креативности. Одним из компонентов исследовательской модели обучения является ученическое исследование. Его алгоритм хорошо описан в педагогической литературе, выявлены общие черты и особенности ученического и научного исследования. Внимание привлекает сходство процесса исследования (в том числе, ученического) с известной схемой Д. Уоллеса, выделившего четыре стадии творческого процесса. Схема Уоллеса представляет линию из четырех отрезков с направлением движения слева направо:

«Подготовка» -------- «Созревание»----------«Озарение»---------«Проверка»

В результате ученического исследования возникает некий продукт - текст. Текст является актом творчества, независимо от степени его научной новизны и общественной пользы. Процесс создания текста учащимся (даже с учетом компилятивности) стимулирует проявление индивидуальности, а также способствует преобразованию интеллектуальных, когнитивных проблем в эмоциональные состояния. Это существенно, так как трансформация когнитивного компонента в эмоциональный является одним из важнейших принципов развития творческих способностей человека.

\section{Литература}

1. Абакумова И.В. Обучение и смысл: смыслообразование в учебном процессе. (Психолого-дидактический подход). Ростов-на-Дону: Изд-во Рост. ун-та, 2003. 
2. Богоявленская Д.Б. Интеллектуальная активность как проблема творчества. Ростовна-Дону: Изд-во Рост. ун-та, 1983.

3. Вишнякова Н.Ф. Креативная психопедагогика. Психология творческого обучения. Ч.1. Минск, 1995.

4. Гузеев В.В. Образовательная технология: от приема до философии. М.: Издательская фирма «Сентябрь», 1996.

5. Лейтес Н. С. Умственные способности и возраст. М., 1971.

6. Маслоу А. Мотивация и личность. СПб.: Питер, 2007.

7. Пархоменко Н.П. Воспитание творческой личности как цель образовательных систем (историко-методологический аспект): Автореф. дис. докт. пед. наук. Минск, 1995.

8. Проблема научного творчества в современной психологии/Под ред. М.Г. Ярошевского. М.: Наука, 1971.

9. Якиманская И.С. Технология личностно-ориентированного обучения в современной школе. М.: Издательская фирма «Сентябрь», 2000. 


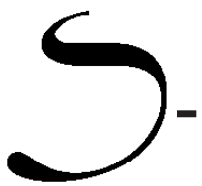

Vursta N.I.

\section{Students' research activity in the focus of creativity development}

One of the conflicts in modern educational environment is a contradiction between Creative development, Creativity and "Technological Ability". The term of "technology" crossed the production borders long time ago and gained new areas of human activity including education. For example, we can find in pedagogical texts the description of the "technology of personality-oriented education" [9]. We will consider Technology of education as a complex consisting of: "image" (presentation) of planned results of education; means of current trainees' state diagnostics; set of education models; criteria of choosing the best model for the current situation [4]. In certain cases technology comes out as an element of method but in the frame of the our discussion we would consider important to think of the technology as the "development" of method, and of the latter as the "reductive technology" which is reflected in students' mind as a trace, as an image of the method" [1].

"Technological process" of education didn't change the educational ideal which represents the development of creative potential of a man [7]. How adequate are educational purposes and means (technologies)? Can pragmatic, structured educational technology at school (in other words models with given result) contribute to the development of creative basis?

The survey of present-day pedagogical and psychological research shows that there exists scientific and practical interest in integrated approach to the problem of co-correspondence between technology of education and development of creative potential. This problem analysis can be found in particular in studies of creativity as a phenomenon of human activity.

The common statement was made that understanding the essence, the nature of creativity, its psychological mechanisms was one of the most difficult tasks for personal psychology and its development. One of the interesting interpretation of creativity was suggested by A. Maslow who differentiated "talent creativity" and "creativity of self-actualization". According to A. Maslow creativity of self-actualization "is spread wider and is closely linked to personality, appearing day by day not only in great and evident creativity products but also in other different abilities, as for example in peculiar sense of humor, in doing anything in a creative way, like teaching... " [6, c. 223] In other words creativity is understood not from the positions of a result (creativity product) and not as a set of personal features (for example, intellectual abilities to generate ideas, to decline stereotypes in thinking, to offer a hypothesis), but as a realization by a person his/her own individuality. The unique human individuality can be seen as a

The article is submitted by the research advisor - the head of Pedagogics and Pedagogical psychology department, Doctor of Pedagogical Science, Professor Fomenko V.T. 
certain creative act that leads to the conception of creativity as a process of showing up one's own personality.

Review of Russian psychologists' texts (V.G. Ananiev, D.B. Bogoyavlenskaya, N.S. Laytes, Y.I Ponomarev and others) that describe the problems of creative abilities development as well creative thinking, let us emphasize a series of statements used in pedagogical science to work out different aspects of students' creativity:

- every student has abilities to creativity; creativity of students and creativity of adults have one common psychological and pedagogical basis;

- differences in demonstrating abilities are seen in the activity that is why effectiveness, speed, dynamic of changes, links with other personal components require individualization of educational process;

- creative abilities can be developed; at the same time the important role is given to so-called transfer mechanism providing succession in developing these abilities in different types of activities;

- creative features and qualities are developed during the process of acquiring educational content and a research of effective technologies must be held as a mechanism of self realization of the content.

The issue of managing the creative process is also substantial. On the one hand there is a tendency to link management with algorithmization of the creative activity, elaboration of methods the use of which could lead to the revelation of something new. Another trend is characterized by negation the direct management of creative activity. It is a matter of creating favorable conditions for creativity.

The most perspective educational technologies are those built on student's research in educational process (research learning, research method). Research methods have been actively used in foreign, mostly English-speaking psychological and pedagogical texts (Klarin V.M.). In Russian science this subject is worked out by Leontovich A.V., Poddyakov A.N., Savenkov A.I. and others.

The research activity (including student's one) represents a special type of intellectual and creative activity appearing as a result of the search activity mechanisms on the basis of research behavior. But if the process of research is always a creativity when at the end a new knowledge appears then we can claim that students' research activity is one of the most important conditions for developing the creative potential of a student. In other words the educational environment based on a research method represents a necessary breeding ground for awakening and developing the creativity. With the help of research activity we overcome conflicts between technological ability and creativity. Our school faces a very serious practical task to create a model of organizing the research activity in complete teaching and educational process. It is important to find in this model a compromise between the requirements of the state set for the education process and the necessary freedom and lack or strict rules for creativity. Thus we have to talk about elaboration and experimental realization of such a model of organizing the research activity in school educational process which could contribute to reveal of own personality of a student. 


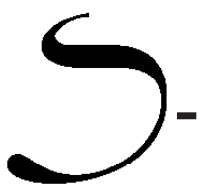

One of the key problems when realizing this model is the search for reliable methods of scientific analysis of creative personality. In particular it concerns the impossibility of creating the valid creativity test because of contradiction between:

- essence of the text as a standardized procedure of survey on given set of parameters;

- essence of the creativity as bounding the frames of given and known (which was noted by the author of one of the most widely use creativity tests - E. Torrance).

There is no doubt that when exploring the results of the model of organizing the research activity in the frame of creative ability development it is necessary to use available methods (Guilford test, D.B. Bogoyavlenskaya's method of creative field and others). On our opinion research education makes additional possibility to analyze the creativity. One of the components of research model of education is student's research. Its algorithm is described in pedagogical books, common features and peculiarities of student's and scientific research are also revealed. The attention is paid to the similarities between the research process (as well as student's one) and the famous scheme of G. Wallis who set down four stages of the creative process. Wallis' scheme presents a line with four segments with moving directions from the left to the right:

«Preparation» -------- «Incubation»----------«lllumination»----------«Verification»

As a result of student's research there appears a certain product - a text. The Text is a creative act regardless of the level of its newness and public utility. The process of students' text creation (even taking into account the compilation) stimulates the demonstration of personality and contributes to the transformation of intellectual, cognitive problems into an emotional state. It is vital as the transformation of a cognitive component into an emotional one is one of the main principles of developing creative abilities of a person.

\section{THE LITERATURE}

1. Abakumova I.V. Education and sense: sense education in teaching process (Psychological and didactical approach). Rostov-on-Don: Rostov University press, 2003.

2. Bogoyavlenskaya D.B. Intellectual activity as a creativity problem. Rostov-on-Don: Rostov University press, 1983.

3. Vishnyakova N.F. Creative psycho-pedagogy. Psychology of creative teaching. Part 1. Minsk, 1995.

4. Guzeev V.V. Educational technology: from techniques to philosophy. M.: Publishing company «September», 1996.

5. Laytes N.S. Mental abilities and the age. M., 1971.

6. Maslow A. Motivaton and personality. St Petersburg, "Peter” press, 2007.

7. Parkhomenko N.P. Education of Creative personality as the goal of educational systems. (historical and methodological aspect): Abstract from the dissertation of Doctor of Pedag.sc. Minsk, 1995.

8. Problem of scientific creativity in contemporary psychology/under M.G. Yaroshevsky. M.: Science, 1971.

9. Yakimanskaya I.S. Technology of personality-oriented education in contemporary school. M.: Publishing company «September», 2000. 